\title{
Development of polymorphic
} microsatellite markers for the critically endangered and endemic Indian dipterocarp, Vateria indica L. (Dipterocarpaceae)

\section{Journal Article}

Author(s):

Ismail, Sascha A.; Buser, Andres; Shaanker, R. Uma; Ravikanth, G.; Ghazoul, Jaboury; Kettle, Chris J.

Publication date:

2013-06

Permanent link:

https://doi.org/10.3929/ethz-b-000066081

Rights / license:

In Copyright - Non-Commercial Use Permitted

Originally published in:

Conservation Genetics Resources 5(2), https://doi.org/10.1007/s12686-012-9829-9 


\title{
Development of polymorphic microsatellite markers for the critically endangered and endemic Indian dipterocarp, Vateria indica L. (Dipterocarpaceae)
}

\author{
Sascha A. Ismail • Andres Buser • R. Uma Shaanker • \\ G. Ravikanth $\cdot$ Jaboury Ghazoul $\cdot$ Chris J. Kettle
}

Received: 19 November 2012/ Accepted: 24 November 2012/Published online: 4 December 2012

(C) Springer Science+Business Media Dordrecht 2012

\begin{abstract}
Vateria indica (Dipterocarpaceae) is an economically and ecologically important canopy tree endemic to the Western Ghats, India. The species has undergone extensive habitat loss and overexploitation and is therefore listed as 'critically endangered' on the 2012 IUCN Red List. We developed ten polymorphic microsatellite loci for $V$. indica. In addition, we confirm cross amplification and variation in two loci isolated from the closely related but geographically disjunct species Vateriopsis seychellarum, previously published by Finger et al. Conserv Genet Resour, 2 (S1):309-311, (2010). The twelve microsatellite primers screened on 48 adult samples of $V$. indica had 5-11 alleles per locus (mean of 8.5 per locus) with an average polymorphic information content of 0.64 across loci. Expected heterozygosity ranged from 0.44 to 0.84 . These markers will enable us to quantify population genetic diversity in habitat fragments and to study fine scale spatial genetic structure and contemporary gene flow.
\end{abstract}

S. A. Ismail $(\bowtie) \cdot$ J. Ghazoul $\cdot$ C. J. Kettle

Department of Environmental Systems Science,

ITES-Ecosystem Management, ETH Zurich,

Universitaetsstrasse 16, 8092 Zurich, Switzerland

e-mail: sascha.ismail@env.ethz.ch

\author{
A. Buser \\ Ecogenics GmbH, Grabenstrasse 11a, Schlieren, \\ 8952 Zurich, Switzerland
}

R. Uma Shaanker

Department of Crop Physiology and School of Ecology and Conservation, University of Agricultural Sciences, Bangalore,

Karnataka, India

G. Ravikanth

Department of Conservation Genetics, Ashoka Trust for Research in Ecology and the Environment,

Bangalore, Karnataka, India
Keywords Gene flow $\cdot$ Microsatellites · Population genetics - Vateria indica $\cdot$ Western Ghats

Vateria indica (Dipterocarpaceae) is an economically and ecologically important canopy tree endemic to the Western Ghats, India. The species is listed as 'critically endangered' on the 2012 IUCN Red List because it has undergone extensive habitat loss and overexploitation (Ashton 1998). Vateria indica also provides non-timber forest products including gum resin used for incense and in traditional medicine for its anti-microbial properties (Grover and Rao 1981).

The genus Vateria is principally bee pollinated (Ashton 1988). Dipterocarp species generally have limited dispersal (Kettle 2012), we thus predict similarly limited dispersal of the wingless fruit of $V$. indica. Understanding the consequences of habitat degradation and fragmentation for genetic diversity and contemporary gene dispersal by pollen and seed in $V$. indica, will help to inform conservation. Furthermore, $V$. indica provides the opportunity to increase our understanding of the reproductive ecology of dipterocarp tree species in highly fragmented habitats (Kettle et al. 2012; Finger et al. 2012).

To this end we developed 10 de novo microsatellite markers for $V$. indica. A 454 sequencing library was generated from size selected sheared fragments of genomic DNA using standard Roche reagents. The 454 library was analyzed on a Roche 454 platform using the GS FLX titanium chemistry. The total 41,308 reads had an average length of 336 base pairs. Of these, 452 contained a microsatellite insert with a tetra- or a trinucleotide of at least 6 repeat units or a dinucleotide of at least 10 repeat units. Suitable primer design was possible in 107 reads, of which 


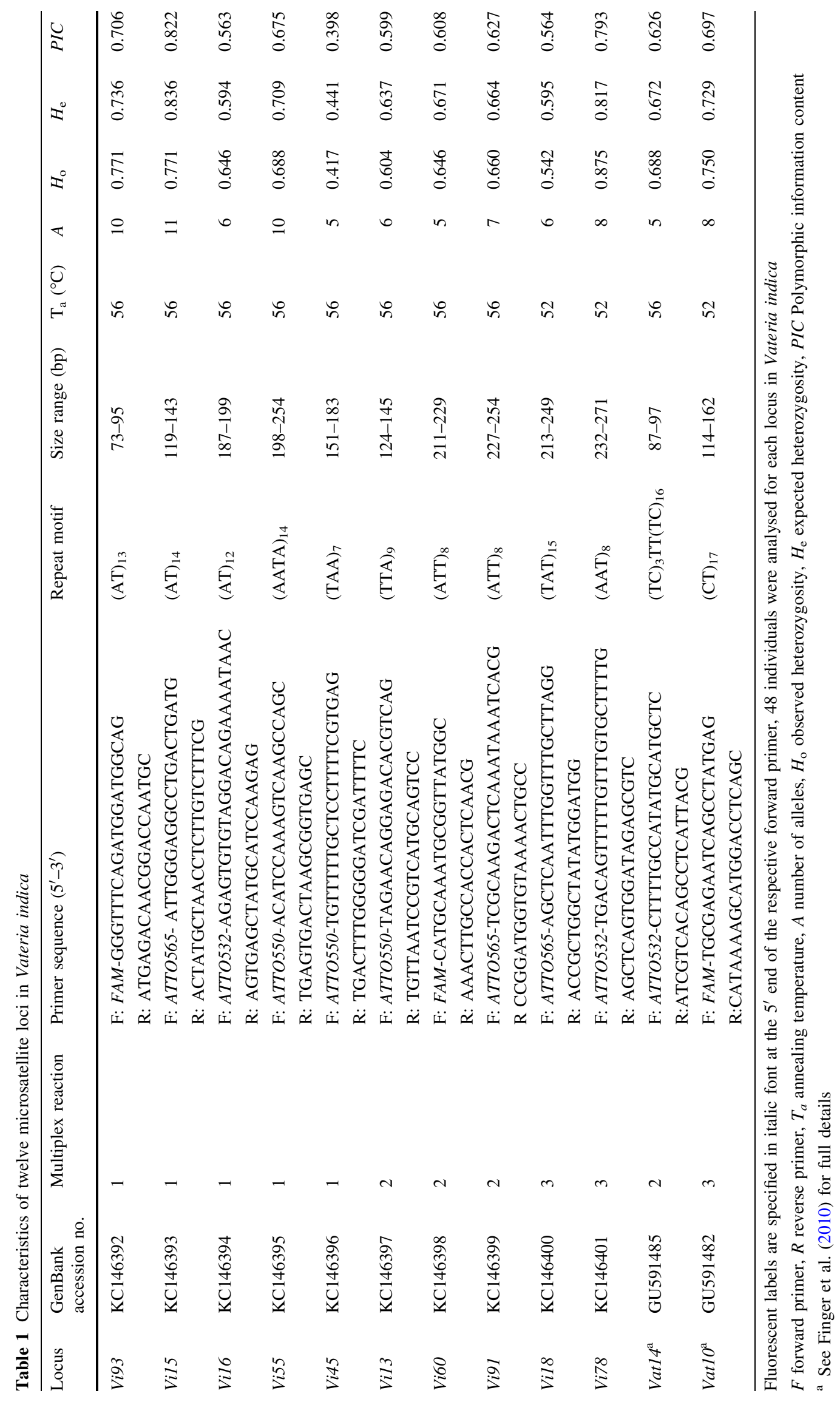


20 were labeled with an M13-tag at its $5^{\prime}$-end described by Schuelke (2000) and tested for polymorphism on 15 samples. Of these 20 primers, the ten most variable loci were optimized and assembled in three multiplex PCR with fluorescent labels on the $5^{\prime}$-end of the forward primer (Table 1). Polymorphism of these ten primers was tested with $48 \mathrm{~V}$. indica adult tree samples collected from a single river catchment in Kodagu district, southern Karnataka, which lies within the Western Ghats biodiversity hotspot.

Genomic DNA was extracted from silica dried leaves of $V$. indica $(n=48)$ using a CTAB extraction method (Sambrook et al. 1989). PCR was carried out in $10.3 \mu \mathrm{L}$ reactions with $2.06 \mu \mathrm{L}$ of $5 \times$ PCR buffer (Promega colorless Flexi GoTaq PCR buffer), $0.66 \mu \mathrm{L}$ of $25 \mathrm{mM}$ $\mathrm{MgCl} 2,1.03 \mu \mathrm{L}$ of $0.2 \mathrm{mM}$ dNTPs, $0.12 \mu \mathrm{L}$ of the $5 \mu \mathrm{M}$ labeled forward primer, $0.25 \mu \mathrm{L}$ of the $10 \mu \mathrm{M}$ unlabeled forward primer, $0.62 \mu \mathrm{L}$ of the $5 \mu \mathrm{M}$ reverse primer, $0.1 \mu \mathrm{L}$ of $5 \mathrm{U} / \mu \mathrm{L} \mathrm{Taq}$ polymerase (Promega), and $1.3 \mu \mathrm{L}$ DNA template $(c .10 \mathrm{ng})$. The missing volume to reach $10.3 \mu \mathrm{L}$ was adjusted for each of the 3 multiplex PCR. PCR were carried out in a Bio-Rad Dyad Cycler with the following cycling conditions: an initial denaturation of $95{ }^{\circ} \mathrm{C}$ for $5 \mathrm{~min}$ followed by 30 cycles of $94{ }^{\circ} \mathrm{C}$ for $30 \mathrm{~s}$, primer-specific temperature $\left(56{ }^{\circ} \mathrm{C}\right.$ for multiplex reaction 1 and 2 or $52{ }^{\circ} \mathrm{C}$ for multiplex reaction 3 ) for $1 \mathrm{~min}$ and $72{ }^{\circ} \mathrm{C}$ for $1 \mathrm{~min}$. The reaction was ended with a final extension time of $72{ }^{\circ} \mathrm{C}$ for $5 \mathrm{~min}$. We used an ABI3730 for fragment analysis and Genemapper 3.5 software (Applied Biosystems) to score the fragments relative to a LIZ 500 size standard.

Descriptive statistics (number of alleles, observed and expected heterozygosities) were generated using GenAlEx 6.4 (Peakall and Smouse 2006). The polymorphism information content (PIC) and deviations from Hardy-Weinberg equilibrium was calculated in Cervus 3.0 (Marshall et al. 1998). Linkage disequilibrium was tested using GENEPOP (Raymond and Rousset 1995) and the resulting $p$-values were adjusted with a sequential Bonferroni correction described in Rice (1989). All twelve loci were polymorphic with 5-11 alleles and a total number of 87 alleles detected over all samples. Observed heterozygosity values ranged from 0.42 to 0.88 and expected heterozygosity from 0.44 to 0.84 . There was no evidence for scoring error due to stuttering or due to large allele dropout and no evidence for the presence of null alleles according to MICROCHECKER 2.2.3 (Van Oosterhout et al. 2004). No significant deviation from Hardy-Weinberg equilibrium was detected in any loci. The test for linkage disequilibrium revealed some association between loci Vi18 and Vi55 and between Vi55 and Vi60 $(p<0.05)$. Two primers isolated from the closely related Seychelles endemic dipterocarp Vateriopsis seychellarum (Finger et al. 2010) also provide useful molecular markers for $V$. indica (see Table 1). These 12 primers will provide a valuable tool for studying the genetic diversity and reproductive ecology in this important Indian tree species.

Acknowledgments We thank Kirsti Määttänen for ensuring that our laboratories run smoothly and for additional support. We also thank Shruthi Jayappa for the single DNA extractions. Fragment analysis was conducted at the Genetic Diversity Center of ETH Zürich. This research was funded under Grant Number ETH-22 08-2 ETH, Zürich.

\section{References}

Ashton PS (1988) Dipterocarp biology as a window to the understanding of tropical forest structure. Annu Rev Ecol Syst 19:347-370

Ashton P (1998) Vateria indica. In: IUCN 2012. IUCN red list of threatened species. Version 2012.2. www.iucnredlist.org. Accessed on 07 Nov 2012

Finger A, Ismail S, Ghazoul J, Kettle CJ (2010) Development of polymorphic microsatellite markers of the endangered and endemic Vateriopsis seychellarum (Dipterocarpaceae), a relict canopy tree of the seychelles. Conserv Genet Resour 2(S1): 309-311

Finger A, Kettle CJ, Kaiser-Bunbury CN, Valentin T, Mougal J, Ghazoul J (2012) Forest fragmentation genetics in a formerly widespread island endemic tree: Vateriopsis seychellarum (Dipterocarpaceae). Mol Ecol 21(10):2369-2382

Grover GS, Rao JT (1981) Anti-microbial properties of the essential oil of Vateria indica. Curr Sci 50(7):316-317

Kettle CJ (2012) Seeding ecological restoration of tropical forests: priority setting under REDD+. Biol Conserv 154:34-41

Kettle CJ, Maycock CR, Burslem D (2012) New directions in dipterocarp biology and conservation: a synthesis. Biotropica 44(5):658-660

Marshall TC, Slate J, Kruuk LEB, Pemberton JM (1998) Statistical confidence for likelihood-based paternity inference in natural populations. Mol Ecol 7(5):639-655

Peakall R, Smouse PE (2006) GENALEX 6: genetic analysis in Excel. Population genetic software for teaching and research. Mol Ecol Notes 6(1):288-295

Raymond M, Rousset F (1995) GENEPOP (version 1.2): population genetics software for exact tests and ecumenicism. J Hered $86: 248-249$

Rice WR (1989) Analyzing tables of statistical tests. Evolution 43(1):223-225

Sambrook J, Fritsch EF, Maniattis T (1989) Molecular cloning: a laboratory manual, 2nd edn. Cold Spring Harbor Laboratory Press, New York

Schuelke M (2000) An economic method for the fluorescent labeling of PCR fragments. Nat Biotechnol 18:233-234

Van Oosterhout C, Hutchinson WF, Wills DPM, Shipley P (2004) Micro-checker: software for identifying and correcting genotyping errors in microsatellite data. Mol Ecol Notes 4(3):535-538 